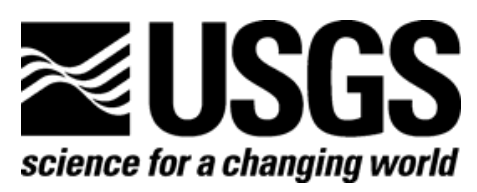

Prepared in cooperation with the Ohio Environmental Protection Agency

\title{
Use of DNA Markers for Investigating Sources of Bacteria in Contaminated Ground Water: Wooster Township, Wayne County, Ohio
}

By Denise H. Dumouchelle

Open-File Report 2006-1382

U.S. Department of the Interior U.S. Geological Survey 


\section{U.S. Department of the Interior DIRK KEMPTHORNE, Secretary}

\section{U.S. Geological Survey \\ Mark D. Myers, Director}

U.S. Geological Survey, Reston, Virginia 2006

For product and ordering information:

World Wide Web: http://www.usgs.gov/pubprod

Telephone: 1-888-ASK-USGS

For more information on the USGS - the Federal source for science about the Earth, its natural and living resources, natural hazards, and the environment:

World Wide Web: http://www.usgs.gov

Telephone: 1-888-ASK-USGS

Suggested citation:

Dumouchelle, D.H., 2006, Selected ground-water-quality data from wells in the Scenic Heights-Batdorf Road area, Wooster Township, Wayne County, Ohio: U.S. Geological Survey Open-File Report 2006-1382, $13 \mathrm{p}$.

Any use of trade, product, or firm names is for descriptive purposes only and does not imply endorsement by the U.S. Government.

Although this report is in the public domain, permission must be secured from the individual copyright owners to reproduce any copyrighted material contained within this report. 


\section{Contents}

Abstract

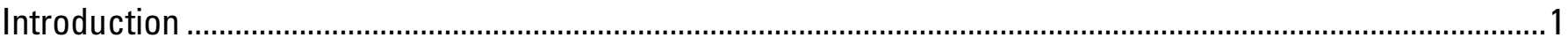

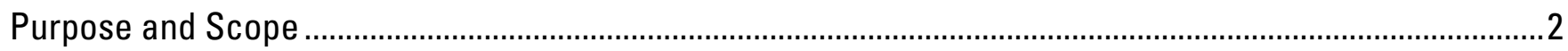

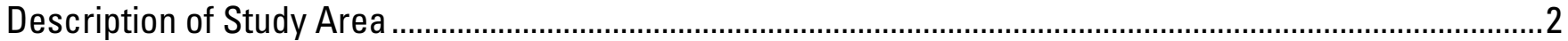

Sampling and Analytical Methods ..................................................................................................................

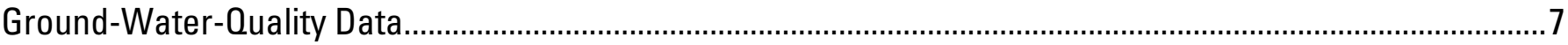

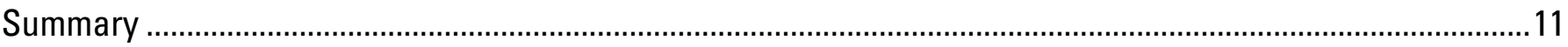

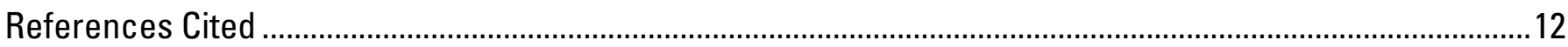

\section{Figure}

1. Map showing location of study area and wells sampled in the Scenic Heights Drive-Batdorf Road area of Wayne County, Ohio. .........................................................................................................

\section{Tables}

1. Wastewater-method compound names, USGS National Water-Quality Laboratory reporting limits, and possible compound uses..

2. Well data and water-quality field data for ground-water samples from wells in the Scenic Heights Drive-Batdorf Road area of Wayne County, Ohio, June 2006 ............................................................ 8

3. Results of bromide, chloride, and nitrate analyses for ground-water samples from wells in the Scenic Heights Drive-Batdorf Road area of Wayne County, Ohio, June 2006 9

4. Results of analyses of bacterial concentrations and bacterial DNA in ground-water samples from wells in the Scenic Heights Drive-Batdorf Road area of Wayne County, Ohio, June $2006 .$. 


\section{Conversion Factors}

\begin{tabular}{lcl}
\hline & Multiply & \multicolumn{1}{c}{ Bo obtain } \\
\hline & Length & \\
\hline inch (in.) & 2.54 & centimeter $(\mathrm{cm})$ \\
inch (in.) & 25.4 & millimeter (mm) \\
foot (ft) & 0.3048 & meter (m) \\
\hline & Volume & \\
gallon (gal) & 3.785 & liter $(\mathrm{L})$ \\
\hline
\end{tabular}

Temperature in degrees Celsius $\left({ }^{\circ} \mathrm{C}\right)$ may be converted to degrees Fahrenheit $\left({ }^{\circ} \mathrm{F}\right)$ as follows: ${ }^{\circ} \mathrm{F}=\left(1.8 \times^{\circ} \mathrm{C}\right)+32$

Small sample volumes are reported in milliliters $(\mathrm{mL})$ and microliters $(\mu \mathrm{L})$. Concentrations of chemical constituents in water are given either in milligrams per liter $(\mathrm{mg} / \mathrm{L})$, micrograms per liter $(\mu \mathrm{g} / \mathrm{L})$, or nanograms per microliter $(\mathrm{ng} / \mu \mathrm{L})$.

Bacteria concentrations are given in colony-forming units per 100 milliliters (CFU/100 mL). 


\title{
Use of DNA Markers for Investigating Sources of Bacteria in Contaminated Ground Water: Wooster Township, Wayne County, Ohio
}

\author{
By Denise H. Dumouchelle
}

\section{Abstract}

In 2004, a public-health nuisance was declared by the Wayne County Board of Health in the Scenic Heights Drive-Batdorf Road area of Wooster Township, Wayne County, Ohio, because of concerns about the safety of water from local wells. Repeated sampling had detected the presence of fecal-indicator bacteria and elevated nitrate concentrations. In June 2006, the U.S. Geological Survey (USGS), in cooperation with the Ohio Environmental Protection Agency (Ohio EPA), collected and analyzed samples from some of the affected wells to help investigate the possibility of human-origin bacterial contamination. Water samples from 12 wells and 5 home sewage-treatment systems (HSTS) were collected. Bromide concentrations were determined in samples from the 12 wells. Samples from 5 of the 12 wells were analyzed for wastewater compounds. Total coliform, enterococci and Escherichia coli (E. coli) bacteria concentrations were determined for samples from 8 of the 12 wells. In addition, two microbial source-tracking tools that employ DNA markers were used on samples from several wells and a composite sample of water from five septic tanks. The DNA markers from the Enterococcus faecium species and the order Bacteroidales are associated with specific sources, either human or ruminant sources.

Bromide concentrations ranged from 0.04 to 0.18 milligrams per liter (mg/L). No wastewater compounds were detected at concentrations above the reporting limits. Samples from the 12 wells also were collected by Ohio EPA and analyzed for chloride and nitrate. Chloride concentrations ranged from 12.6 to $61.6 \mathrm{mg} / \mathrm{L}$ and nitrate concentrations ranged from 2.34 to $11.9 \mathrm{mg} / \mathrm{L}$ (as $\mathrm{N}$ ).

Total coliforms and enterococci were detected in samples from 8 wells, at concentrations from 2 to 200 colony-forming units per 100 milliliters (CFU/100 mL) and 0.5 to $17 \mathrm{CFU} / 100 \mathrm{~mL}$, respectively. $E$. coli were detected in samples from three of the eight wells, at concentrations of 1 or 2 CFU/100 mL. Tests for the human-specific marker of enterococci, the esp gene, were negative in the seven samples tested, including the composite sample of HSTS water. DNA with the general Bacteroidales marker was detected in samples from four wells, but the tests for both the human- and ruminant-associated markers were negative. The presence of the PCR (polymerase chain reaction)-detectable DNA for the general fecal Bacteroidales marker is indicative of fecal contamination and recently recharged water.

\section{Introduction}

In October 2004, the Wayne County Board of Health declared a public-health nuisance in the Scenic Heights Drive-Batdorf Road area of Wooster Township, Ohio (fig. 1) because of concerns about the safety of the local water supply. In January 2006, at the request of Wayne County officials, the Ohio Environmental Protection Agency (Ohio EPA) began an investigation. Repeated sampling of the private water wells in the area found elevated nitrate concentrations and total coliform and Escherichia coli (E. 
coli) bacteria on multiple occasions (Ohio Environmental Protection Agency, 2006). One possible source of contamination is nearby home sewage-treatment systems (HSTS); other possible sources include domestic pets and wildlife (bacteria) and fertilizers (nitrate).

Several water-quality and microbial source tracking (MST) methods can be used to indicate sewage contamination. Unfortunately, other potential sources can complicate interpretation of the data from many of these methods. Therefore, studies have found that use of multiple methods, including chemical and microbiological indicators, is the best approach for evaluating potential sewage contamination (K. E. Hyer, U.S. Geological Survey, written commun., 2006; Dumouchelle, 2006; Noble and others, 2006). To help identify whether the observed bacterial contamination originated from a human source, the U.S. Geological Survey (USGS), in cooperation with the Ohio EPA, collected and analyzed samples from wells in the Scenic Heights Drive-Batdorf Road area. In particular, the USGS used two MST tools that employ human-associated DNA markers found in bacterial strains of the order Bacteroidales and the species Enterococcus faecium (Bernhard and Field, 2000; Dick and others, 2005; Scott and others, 2005). Additionally, the presence of the general Bactroidales marker was used as another indicator of fecal contamination. The USGS Ohio Water Science Center is testing MST methods for their utility in combination with more traditional tools for contaminant-source identification. The present study is one of several case studies in Ohio.

\section{Purpose and Scope}

The purpose of this report is to present data from ground-water samples collected from selected residential wells in the Scenic Heights Drive-Batdorf Road area and to describe the use of DNA markers for investigating the sources of bacteria in contaminated ground water. In June 2006, the USGS collected and analyzed water samples from 12 wells and 5 HSTS. Bromide concentrations were determined at all 12 wells. Wastewater compounds were analyzed in samples from 5 of the 12 wells. Total coliform, enterococci, and E. coli bacteria concentrations were determined for samples from 8 of the 12 wells. Analysis of DNA markers was done on water samples from seven wells. A composite sample of HSTS water from 5 of the 12 properties where wells were sampled was analyzed for DNA markers.

Ohio EPA concurrently collected water from the same 12 wells and analyzed the samples for chloride and nitrate concentrations. Data from samples collected and analyzed by the Ohio EPA also are presented.

\section{Description of the Study Area}

The study area is in Wooster Township, southwest of the city of Wooster in northeastern Ohio, near the intersection of Batdorf and Tolbert Roads (fig. 1). The land use is rural residential, with most homes on lots ranging from half an acre to more than an acre. The homes are served by residential water wells and leach-line HSTSs. The residential wells in the area are from 70 to $185 \mathrm{ft}$ deep and are completed as open holes in fractured sandstone, siltstone, and shale. The Ohio Department of Health used a downhole camera in July 2003 to investigate a well in the vicinity of WN-36 (fig. 1), and numerous fractures and openings were observed both above and below the water level (Craig Smith, Ohio Environmental Protection Agency, written commun., 2006). In addition, during the sampling for the current study, cascading water was heard in one well (WN-40). 

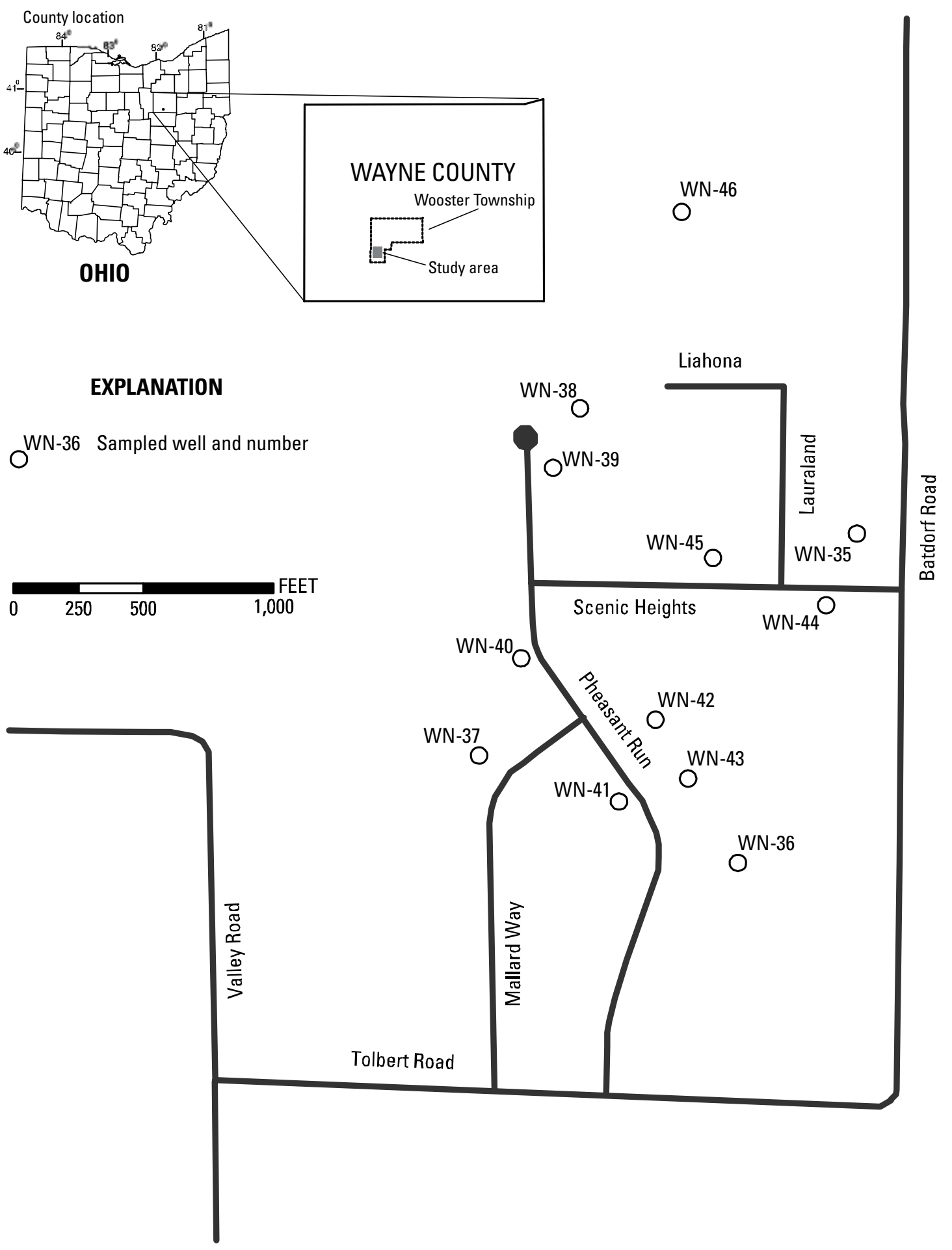

Figure 1. Location of study area and wells sampled in Scenic Heights Drive-Batford Road area, Wayne County, Ohio. 


\section{Sampling and Analytical Methods}

Selection of wells was based on results of previous sampling by various agencies. Five wells with frequent detections of fecal-indicator bacteria were selected for analysis of wastewater compounds, bacteria, and bromide. Three additional wells were selected for analysis of bacteria and bromide. Another three wells were selected for the analysis of bromide only. A twelfth well, just north of study area, was sampled and analyzed for bromide to obtain background concentration data.

Homeowners of the selected wells gave permission for sampling and identified household spigots from which untreated water could be drawn. All samples were collected from these spigots as supplied by existing plumbing and well pumps. In most cases, an outside spigot was used as the sampling point. Sterile tubing and fittings were connected to the spigot for purging and sample collection. Although the sampled wells were in regular use, all wells were purged before sample collection. During purging, field measurements of $\mathrm{pH}$, specific conductance, dissolved oxygen concentration, and temperature were made. Water samples were collected after the field measurements had stabilized.

The wastewater compounds and bromide analyses were done by the USGS National Water-Quality Laboratory in Denver, Colo. Bromide analyses were done by ion chromatograpy, with a reporting limit of $0.02 \mathrm{mg} / \mathrm{L}$. The wastewater compounds and detection limits are given in table 1; analytical methods used are documented in Zaugg and others (2002). A field blank sample also was collected and analyzed for wastewater compounds to determine potential contamination from field and transport procedures.

Bacterial analyses were done at the USGS Ohio Water Microbiology Laboratory in Columbus, Ohio. Samples were analyzed within 26 hours of collection for total coliforms and $E$. coli by use of the MI membrane-filtration method (U.S. Environmental Protection Agency, 2002a) and for enterococci using the mEI membrane-filtration method (U.S. Environmental Protection Agency, 2002b). Because of the need to collect enterococci colonies for DNA analysis, up to $1 \mathrm{~L}$ of sample water was filtered, which is more than the standard $100 \mathrm{~mL}$ filtered for the method. The MST methods that can detect the presence of genetic markers within the order Bacteroidales and the species Enterococcus faecium were used to try to determine whether fecal contamination included a human source. Water samples were tested for the presence of a general fecal, human-associated, and ruminate-associated marker in the order Bacteroidales, as described in Dick and others (2005), according to the protocol originally described by Bernhard and Field (2000). Water samples were tested for the presence of Enterococcus faecium human-specific esp marker (enterococci marker) according to the protocol originally described by Scott and others (2005). About $500 \mathrm{~mL}$ of wastewater was collected from 5 septic tanks and combined into a single sample that also was analyzed for bacterial DNA markers.

Procedures for the microbiology quality-assurance/quality-control (QA/QC) laboratory practices are described in Francy and others (2005). In the laboratory, filter blanks were included for at least every third E. coli sample (and every sample for Bacteroidales or enterococci markers) to document that filtration equipment and buffered water were not contaminated.

Control DNA for human contamination sources (Delaware, Ohio, wastewater influent sample) and ruminant contaminant sources (Delaware, Ohio, cattle feces) were similarly processed for the presence of the Bacteroidales and enterococci markers. The presence of the general Bacteroidales marker (Bac32) was used as evidence that the polymerase chain reaction (PCR) was successful; in the absence of a positive response for Bac32, a matrix spike was included. For the enterococci marker, matrix spikes were included for each environmental sample, including the composite HSTS sample, to identify any possible matrix inhibition. PCR reagent blanks were included to test for contamination of PCR reagents with amplifiable target DNA. 
Table 1. Wastewater-method compound names, USGS National Water-Quality Laboratory reporting limits, and possible compound uses (modified from Zaugg and others, 2002).

[Laboratory reporting limits are in micrograms per liter; F, fungicide; H, herbicide; I, insecticide; GUP, general-use pesticide; FR, flame retardant; WW, wastewater; Manuf, manufacturing; \%, percent; >, greater than; CP, combustion product; UV, ultraviolet]

\begin{tabular}{|c|c|c|}
\hline Compound name & $\begin{array}{c}\text { Laboratory } \\
\text { reporting } \\
\text { limit }\end{array}$ & Possible compound uses or sources \\
\hline 1,4-Dichlorobenzene & 0.5 & Moth repellant, fumigant, deodorant \\
\hline 17beta-Estradiol & 5 & Estrogen replacement therapy, estrogen metabolite \\
\hline 1-Methylnaphthalene & 0.5 & $2-5 \%$ of gasoline, diesel fuel, or crude oil \\
\hline 2,6-Dimethylnaphthalene & 0.5 & Present in diesel/kerosene (trace in gasoline) \\
\hline 2-Methylnaphthalene & 0.5 & $2-5 \%$ of gasoline, diesel fuel, or crude oil \\
\hline 3beta-Coprostanol & 2 & Carnivore fecal indicator \\
\hline 3-Methyl-1H-indole (skatol) & 1 & Fragrance, stench in feces and coal tar \\
\hline 3-tert-Butyl-4-hydroxyanisole (BHA) & 5 & Antioxidant, general preservative \\
\hline 4-Cumylphenol & 1 & Nonionic detergent metabolite \\
\hline 4- $n$-Octylphenol & 1 & Nonionic detergent metabolite \\
\hline 4-tert-Octylphenol & 1 & Nonionic detergent metabolite \\
\hline 5-Methyl-1H-benzotriazole & 2 & Antioxidant in antifreeze and deicers \\
\hline Acetophenone & 0.5 & Fragrance in detergent and tobacco, flavor in beverages \\
\hline $\begin{array}{l}\text { Acetyl-hexamethyl-tetrahydro-naphthalene } \\
\text { (AHTN) }\end{array}$ & 0.5 & Musk fragrance (widespread usage) persistent in ground water \\
\hline Anthracene & 0.5 & Wood preservative, component of tar, diesel, or crude oil, CP \\
\hline Anthraquinone & 0.5 & Manuf dye/textiles, seed treatment, bird repellant \\
\hline Benzo $[a]$ pyrene & 0.5 & Regulated PAH, used in cancer research, CP \\
\hline Benzophenone & 0.5 & Fixative for perfumes and soaps \\
\hline beta-Sitosterol & 2 & Plant sterol \\
\hline beta-Stigmastanol & 2 & Plant sterol \\
\hline Bisphenol A & 1 & Manuf polycarbonate resins, antioxidant, FR \\
\hline Bromacil & 0.5 & H (GUP), $>80 \%$ noncrop usage on grass/brush \\
\hline Bromoform & 0.5 & WW ozonation byproduct, military/explosives \\
\hline Caffeine & 0.5 & Beverages, diuretic, very mobile/biodegradable \\
\hline Camphor & 0.5 & Flavor, odorant, ointments \\
\hline Carbaryl & 1 & I, crop and garden uses, low persistence \\
\hline Carbazole & 0.5 & I, Manuf dyes, explosives, and lubricants \\
\hline Chlorpyrifos & 0.5 & $\begin{array}{l}\text { I, domestic pest and termite control (domestic use restricted as of } \\
\text { 2001) }\end{array}$ \\
\hline Cholesterol & 2 & Often a fecal indicator, also a plant sterol \\
\hline Cotinine & 1 & Primary nicotine metabolite \\
\hline Diazinon & 0.5 & I, $>40 \%$ nonagricultural usage, ants, flies \\
\hline Dichlorvos & 1 & I, pet collars, flies, also a degradate of naled or trichlofon \\
\hline$d$-Limonene & 0.5 & $\mathrm{~F}$, antimicrobial, antiviral, fragrance in aerosols \\
\hline Equilenin & 5 & Hormone replacement therapy drug \\
\hline Estrone & 5 & Biogenic hormone \\
\hline
\end{tabular}


Table 1. Wastewater method compound names, USGS National Water-Quality Laboratory reporting limits, and possible compound uses.-Continued

\begin{tabular}{|c|c|c|}
\hline Compound name & $\begin{array}{c}\text { Laboratory } \\
\text { reporting } \\
\text { limit }\end{array}$ & Possible compound uses or sources \\
\hline Ethynyl estradiol & 5 & Oral contraceptive \\
\hline Fluoranthene & 0.5 & $\begin{array}{l}\text { Component of coal tar and asphalt (only traces in gasoline or diesel } \\
\text { fuel), CP }\end{array}$ \\
\hline $\begin{array}{l}\text { Hexahydrohexamethyl- } \\
\text { cyclopentabenzopyran (HHCB) }\end{array}$ & 0.5 & Musk fragrance (widespread usage) persistent in ground water \\
\hline Indole & 0.5 & Pesticide inert ingredient, fragrance in coffee \\
\hline Isoborneol & 0.5 & Fragrance in perfumery, in disinfectants \\
\hline Isophorone & 0.5 & Solvent for lacquer, plastic, oil, silicon, resin \\
\hline Isopropylbenzene (cumene) & 0.5 & Manuf phenol/acetone, fuels and paint thinner \\
\hline Isoquinoline & 0.5 & Flavors and fragrances \\
\hline Menthol & 0.5 & Cigarettes, cough drops, liniment, mouthwash \\
\hline Metalaxyl & 0.5 & H, F (GUP), mildew, blight, pathogens, golf/turf \\
\hline Methyl salicylate & 0.5 & Liniment, food, beverage, UV-absorbing lotion \\
\hline Metolachlor & 0.5 & $\mathrm{H}$ (GUP), indicator of agricultural drainage \\
\hline N,N-diethyl-meta-toluamide (Deet) & 0.5 & I, urban uses, mosquito repellent \\
\hline Naphthalene & 0.5 & $\begin{array}{l}\text { Fumigant, moth repellent, major component (about 10\%) of } \\
\text { gasoline }\end{array}$ \\
\hline Nonylphenol, diethoxy- (total, NPEO2) & 5 & Nonionic detergent metabolite \\
\hline Octylphenol, diethoxy- (OPEO2) & 1 & Nonionic detergent metabolite \\
\hline Octylphenol, monoethoxy- (OPEO1) & 1 & Nonionic detergent metabolite \\
\hline para-Cresol & 1 & Wood preservative \\
\hline para-Nonylphenol (total) & 5 & Nonionic detergent metabolite \\
\hline Pentachlorophenol & 2 & $\mathrm{H}, \mathrm{F}$, wood preservative, termite control \\
\hline Phenanthrene & 0.5 & Manuf explosives, component of tar, diesel fuel, or crude oil, CP \\
\hline Phenol & 0.5 & Disinfectant, manuf several products, leachate \\
\hline Prometon & 0.5 & $\mathrm{H}$ (noncrop only), applied prior to blacktop \\
\hline Pyrene & 0.5 & $\begin{array}{l}\text { Component of coal tar and asphalt (only traces in gasoline or diesel } \\
\text { fuel), CP }\end{array}$ \\
\hline Tetrachloroethylene & 0.5 & Solvent, degreaser, veterinary anthelmintic \\
\hline Tri(2-chloroethyl) phosphate & 0.5 & Plasticizer, flame retardant \\
\hline Tri(dichloroisopropyl) phosphate & 0.5 & Flame retardant \\
\hline Tributyl phosphate & 0.5 & Antifoaming agent, flame retardant \\
\hline Triclosan & 1 & $\begin{array}{l}\text { Disinfectant, antimicrobial (concern for acquired microbial } \\
\text { resistance) }\end{array}$ \\
\hline Triethyl citrate (ethyl citrate) & 0.5 & Cosmetics, pharmaceuticals \\
\hline Triphenyl phosphate & 0.5 & Plasticizer, resin, wax, finish, roofing paper, FR \\
\hline Tri(2-butoxyethyl) phosphate & 0.5 & Flame retardant \\
\hline
\end{tabular}




\section{Ground-Water-Quality Data}

Data on the wells and the onsite measurements $(\mathrm{pH}$, specific conductance, temperature, and dissolved oxygen (DO)) are listed in table 2 . The $\mathrm{pH}$, specific conductance, and temperature values are typical for ground water from bedrock in northeastern Ohio (Eberts and others, 1990; Jagucki and Darner, 2001); however, the DO concentrations are unusually high for ground water. Although the use of the residential well pumps in the sample collection could introduce some oxygen into the water, the DO concentrations are still unusually high. In general, DO concentrations in ground water are expected to be less than $0.1 \mathrm{mg} / \mathrm{L}$ because buried organic matter and oxidizable minerals deplete available oxygen quickly; however, ground water in recharge areas can have relatively high DO concentrations, similar to concentrations in surface water (Hem, 1989; Freeze and Cherry, 1979). The DO concentrations measured in the wells in this study are consistent with recently recharged water.

Bromide concentrations from 12 ground-water samples ranged from 0.04 to $0.18 \mathrm{mg} / \mathrm{L}$ (table 3 ). Samples were collected concurrently by Ohio EPA and analyzed by their laboratory for chloride and nitrate $^{1}$ concentrations (table 3 ). Chloride concentrations ranged from 12.6 to $61.6 \mathrm{mg} / \mathrm{L}$. Nitrate concentrations ranged from 2.34 to $11.9 \mathrm{mg} / \mathrm{L}$ (as $\mathrm{N}$ ). Water samples from three of the wells had nitrate concentrations that exceeded the Maximum Contaminant Level of $10 \mathrm{mg} / \mathrm{L}$ (U.S. Environmental Protection Agency, 2004). Samples from 10 of the wells had nitrate concentrations greater than $3.1 \mathrm{mg} / \mathrm{L}$; in Ohio, this may indicate effects of human activity (Baker and others, 1989). High nitrate concentrations are not common in ground water because aquifers are normally low in oxygen, forcing soil bacteria to strip oxygen from nitrate. These nitrate concentrations are consistent with the high DO concentrations described earlier.

Samples from eight wells were collected and analyzed for bacteria concentrations (table 4). Enterococci bacteria were found in samples from every well, although the concentrations in samples from three wells were less than $0.5 \mathrm{CFU} / 100 \mathrm{~mL}$ (volumes filtered were greater than $100 \mathrm{~mL}$ ). Total coliforms were found in samples from every well at concentrations from 2 to $200 \mathrm{CFU} / 100 \mathrm{~mL}$. E. coli were found in samples from three wells at concentrations greater than $1 \mathrm{CFU} / 100 \mathrm{~mL}$.

Concentrations of enterococci from wells WN-37, WN-39, WN-40, WN-42, and WN-43 did not allow for the collection of more than 100 colonies for the DNA-marker analysis. This is significant because Scott and others (2005) reported consistent detection of the esp gene in human-derived enterococci when at least 100 colonies were cultivated. Regardless, the colonies were tested for the presence of the esp gene. The presence of this gene indicates fecal contamination from a human source; the absence of the gene indicates either that fecal contamination is from nonhuman sources, or that the enterococci concentrations from human sources were below the detection limit, or that the marker was not present in the fecal source. The esp gene was not found in any of the samples, including the composite sample from five septic tanks (table 4). In another study, the esp gene was reported to be present in 8 of 10 septic-system samples that had enterococci concentrations of $58 \pm 24 \mathrm{CFU} / 100 \mathrm{~mL}$ (Scott and others, 2005), so the failure to detect the marker in the composite sample with 51,000 CFU/100 mL is a strong indication that the gene would not have been detected in the ground-water samples even if the enterococci concentrations were greater. Therefore, the fecal contamination in the wells is likely from either human sources that did not have the marker or from nonhuman sources.

\footnotetext{
${ }^{1}$ Actual analysis was for nitrite plus nitrate; however, "nitrate" is used in this report for simplicity because the proportion of nitrite to nitrate is negligible in most ground water.
} 
Table 2. Well data and water-quality field data for ground-water samples from wells in the Scenic Heights Drive-Batdorf Road area of Wayne County, Ohio, June 2006

$[\mu \mathrm{S} / \mathrm{cm}$, microsiemens per centimeter at 25 degrees Celsius; deg. C, degrees Celsius; mg/L, milligrams per liter; U, unknown; <, less than; --, no data]

\begin{tabular}{|c|c|c|c|c|c|c|c|}
\hline $\begin{array}{c}\text { Site } \\
\text { name }\end{array}$ & $\begin{array}{c}\text { Date } \\
\text { sampled }\end{array}$ & $\begin{array}{l}\text { Approximate } \\
\text { depth of } \\
\text { well/length } \\
\text { of casing } \\
\text { (feet) }\end{array}$ & $\begin{array}{l}\text { Depth to } \\
\text { water, below } \\
\text { ground } \\
\text { surface } \\
\text { (feet) }\end{array}$ & $\begin{array}{c}\text { pH } \\
\text { (standard } \\
\text { units) }\end{array}$ & $\begin{array}{c}\text { Specific } \\
\text { conductance } \\
(\mu \mathrm{S} / \mathrm{cm})\end{array}$ & $\begin{array}{c}\text { Temperature, } \\
\text { water } \\
\text { (deg. C) }\end{array}$ & $\begin{array}{l}\text { Dissolved } \\
\text { oxygen } \\
\text { (mg/L) }\end{array}$ \\
\hline WN-35 & $6-21-2006$ & $150 * / \mathrm{U}$ & 102 & 7.0 & 485 & 13.0 & 9.45 \\
\hline WN-36 & $6-21-2006$ & $118 / 70$ & $59.7 * *$ & 6.9 & 430 & 12.2 & 1.26 \\
\hline WN-37 & 6-19-2006 & $80 * / \mathrm{U}$ & 29.4 & 6.3 & 417 & 13.1 & 8.56 \\
\hline WN-38 & $6-21-2006$ & $140 / 116$ & 94.8 & 6.5 & 298 & 11.3 & 6.77 \\
\hline WN-39 & $6-20-2006$ & $140 * / \mathrm{U}$ & 82.4 & 6.3 & 273 & 13.0 & 7.65 \\
\hline WN-40 & $6-19-2006$ & $116 / 52$ & 51.6 & 6.6 & 465 & 13.8 & 6.51 \\
\hline WN-41 & $6-20-2006$ & $135 / 79$ & 55.0 & 7.0 & 466 & 13.5 & 2.25 \\
\hline WN-42 & $6-20-2006$ & $140 * / \mathrm{U}$ & 65.8 & 6.5 & 361 & 13.2 & 6.73 \\
\hline WN-43 & $6-20-2006$ & $100 / 79$ & 63.0 & 6.5 & 355 & 12.6 & 4.04 \\
\hline WN-44 & $6-21-2006$ & $140 * / \mathrm{U}$ & 104.3 & 7.0 & 554 & 12.8 & 4.96 \\
\hline WN-45 & 6-19-2006 & $150 / 120$ & 98.0 & 6.8 & 422 & 12.9 & 4.59 \\
\hline WN-46 & 6-19-2006 & -- & -- & 7.0 & 618 & 12.7 & 7.15 \\
\hline
\end{tabular}

\footnotetext{
* Reported by the Ohio Environmental Protection Agency.
}

** Depth to water is below the top of casing. 
Table 3. Results of bromide, chloride, and nitrate analyses for groundwater samples from wells in the Scenic Heights Drive-Batdorf Road area of Wayne County, Ohio, June 2006.

[Samples for chloride and nitrate analyses were collected and analyzed by the Ohio Environmental Protection Agency; mg/L, milligrams per liter]

\begin{tabular}{lccc}
\hline $\begin{array}{c}\text { Site } \\
\text { name }\end{array}$ & $\begin{array}{c}\text { Bromide, } \\
\text { dissolved } \\
\text { (mg/L) }\end{array}$ & $\begin{array}{c}\text { Chloride, } \\
\text { dissolved } \\
\text { (mg/L) }\end{array}$ & $\begin{array}{c}\text { Nitrite + nitrate, } \\
\text { (mg/L } \\
\text { as N) }\end{array}$ \\
\hline WN-35 & 0.19 & 43.6 & 11.9 \\
WN-36 & .07 & 39.7 & 2.34 \\
WN-37 & .14 & 59.2 & 9.87 \\
WN-38 & .09 & 13.0 & 10.9 \\
WN-39 & .16 & 12.6 & 11.3 \\
WN-40 & .18 & 61.6 & 9.15 \\
WN-41 & .06 & 37.1 & 2.42 \\
WN-42 & .12 & 37.2 & 8.66 \\
WN-43 & .08 & 46.8 & 5.88 \\
WN-44 & .05 & 28.0 & 6.50 \\
WN-45 & .05 & 53.2 & 5.08 \\
WN-46 & & & 5.5 \\
\hline
\end{tabular}


Table 4. Results of analyses of bacteria concentrations and bacterial DNA in ground-water samples from wells in the Scenic Heights Drive-Batdorf Road area of Wayne County, Ohio, June 2006.

[CFU/100 mL, colony-forming units per 100 milliliters; <, less than; E, results based on estimated colony count; $\mathrm{k}$, results based on colony count outside of the ideal range, potentially reducing accuracy of estimates; g, present at concentrations less than 0.5 colonies per 100 milliliters; --, not determined; Pos., positive for detection of bacterial DNA marker; Neg., negative for detection of bacterial DNA marker]

\begin{tabular}{|c|c|c|c|c|c|c|c|}
\hline \multirow{2}{*}{ Site name } & \multirow{2}{*}{$\begin{array}{l}\text { Enterococci }{ }^{\mathrm{a}} \\
\text { (CFU/100mL) }\end{array}$} & \multirow{2}{*}{$\begin{array}{c}\text { Total } \\
\text { Coliform } \\
\text { (CFU/100mI) }\end{array}$} & \multirow{2}{*}{$\begin{array}{c}\text { E. coli }{ }^{\mathrm{a}} \\
\text { (CFU/100mL) }\end{array}$} & \multirow{2}{*}{$\begin{array}{l}\text { Enterococcus } \\
\text { esp marker } \\
\text { present }\end{array}$} & \multicolumn{3}{|c|}{$\begin{array}{l}\text { Bacteroidales }^{\mathrm{C}} \\
\text { markers present }\end{array}$} \\
\hline & & & & & Fecal & Human & Ruminant \\
\hline WN-36 & $g^{d}$ & $14 \mathrm{E}, \mathrm{k}$ & $<1$ & -- & Neg. & -- & -- \\
\hline WN-37 & $17 \mathrm{E}, \mathrm{k}$ & $200 \mathrm{E}, \mathrm{k}$ & $1 \mathrm{E}, \mathrm{k}$ & Neg. & Pos. & Neg. & Neg. \\
\hline WN-39 & $2 \mathrm{E}, \mathrm{k}$ & $28 \mathrm{E}$ & $2 \mathrm{E}, \mathrm{k}$ & Neg. & Neg. & -- & -- \\
\hline WN-39 replicate & $2 \mathrm{E}, \mathrm{k}$ & $9 \mathrm{E}, \mathrm{k}$ & $<1$ & Neg. & Neg. & -- & -- \\
\hline $\mathrm{WN}-40$ & $2 \mathrm{E}, \mathrm{k}$ & $32 \mathrm{E}$ & $1 \mathrm{E}, \mathrm{k}$ & Neg. & Pos. & Neg. & Neg. \\
\hline WN-41 & $g^{d}$ & $2 \mathrm{E}, \mathrm{k}$ & $<1$ & -- & -- & -- & -- \\
\hline WN-42 & $2 \mathrm{E}, \mathrm{k}$ & $26 \mathrm{E}$ & $<1$ & Neg. & Pos. & Neg. & Neg. \\
\hline WN-43 & $2 \mathrm{E}, \mathrm{k}$ & $16 \mathrm{E}, \mathrm{k}$ & $<1$ & Neg. & Pos. & Neg. & Neg. \\
\hline WN-45 & $g^{d}$ & $4 \mathrm{E}, \mathrm{k}$ & $<1$ & -- & Neg. & -- & -- \\
\hline $\begin{array}{l}\text { Septic } \\
\text { composite }\end{array}$ & $51,000 \quad \mathrm{E}$ & -- & -- & Neg. & -- & Pos. & Neg. \\
\hline
\end{tabular}

${ }^{a}$ Samples were processed within 26 hours of collection.

${ }^{\mathrm{b}}$ The esp marker is on a gene in the Enterococcus faecium DNA that is specific to bacteria from a human source. Presence of the marker indicates fecal contamination of human origin but does not indicate humans as a dominant source. Absence of the marker indicates either no human-origin fecal contamination or concentrations less than the minimum detection limit.

${ }^{\mathrm{c}}$ The presence of the general fecal Bacteroidales marker indicates fecal contamination. The presence of the human-associated or ruminant-associated marker indicates human or ruminant sources contributed to the fecal contamination. The absence of a marker indicates either no associated host-source for the fecal contamination or that the concentrations were less than the minimum detection limit.

${ }^{d}$ Concentrations less than $1 \mathrm{CFU} / 100 \mathrm{~mL}$ were determined by filtering up to 1 liter of water. 
Samples from seven wells were analyzed for the detection of the general fecal Bacteroidales marker; four were positive (table 4). DNA samples from these four wells were then tested for the host-specific, humanand ruminant-associated markers; all tests for host-specific markers were negative. The presence of the general fecal marker indicates fecal contamination. Although the presence of the human- or ruminantassociated marker indicates human or ruminant sources contributed to the contamination, the absence of the marker may indicate one or more of the following situations: (1) there was no fecal contamination from the host-associated sources, (2) the amount of contamination from the host-associated sources was below the detection limit of the method, or (3) the marker was not present in the fecal sources or was not present at expected concentrations.

Fecal bacteria of the order Bacteroidales are anaerobes and are expected to survive for only a relatively short time in oxygenated waters. A study by Kreader (1998) found that in river water at $4^{\circ} \mathrm{C}$, PCR-detectable DNA from Bacteroidales was detectable for at least 2 weeks; at $14^{\circ} \mathrm{C}$, the DNA was detectable for only 4 to 5 days. Given the temperatures in the sampled water in this study $\left(11-13^{\circ} \mathrm{C}\right)$, the presence of detectable DNA from Bacteroidales in samples from four wells - WN37, WN-40, WN-42, and $\mathrm{WN}-43$ - is indicative of recently recharged water.

Water from five wells - WN-37, WN-39, WN-40, WN-42 and WN-43 - was sampled and analyzed for wastewater compounds (table 1). Metolachlor, an herbicide and general-use pesticide and an indicator of agricultural drainage (table 1), was detected in all five samples but at concentrations below the laboratory reporting limit of $0.5 \mu \mathrm{g} / \mathrm{L}$ (data on file at the USGS Ohio Water Science Center). The estimated concentrations of metolachlor ranged from 0.0102 to $0.1160 \mu \mathrm{g} / \mathrm{L}$. The only other compound detected was caffeine, in the sample from WN-40; the concentration was estimated at $0.120 \mu \mathrm{g} / \mathrm{L}$, below the reporting limit of $0.5 \mu \mathrm{g} / \mathrm{L}$.

\section{Summary}

In 2004, a public-health nuisance was declared by the Wayne County Board of Health in the Scenic Heights Drive-Batdorf Road area of Wooster Township, Wayne County, Ohio, because of concerns about the safety of water from local wells. Repeated sampling of the private water wells had found elevated nitrate concentrations and the fecal-indicators total coliform and Escherichia coli (E. coli). To help identify whether the bacterial contamination was from a human source, the U.S. Geological Survey (USGS), in cooperation with the Ohio Environmental Protection Agency (Ohio EPA), collected and analyzed samples from some of the affected residential water wells. The wells in the area are completed as open holes in fractured bedrock. In June 2006, the USGS collected water samples from 12 wells and 5 septic tanks. Bromide concentrations were analyzed in samples from all 12 wells. Samples from 5 of the 12 wells were analyzed for wastewater compounds. Total coliform, enterococci, and E. coli bacteria concentrations were determined in samples from 8 of the 12 wells. In addition, two microbial source tracking (MST) tools that employ DNA markers were tested on several samples from wells and a composite sample of water from 5 septic tanks. The DNA markers from the Enterococcus faecium species and the order Bacteroidales are associated with specific sources, either human or ruminant. The general Bacteriodales marker is also an indicator of fecal contamination from warmblooded animals.

Onsite measurements of $\mathrm{pH}$, temperature, specific conductance, and dissolved oxygen were made during sampling. The unexpectedly high concentrations of dissolved oxygen, ranging from 1.26 to 9.45 $\mathrm{mg} / \mathrm{L}$, are indicative of recently recharged waters. Bromide concentrations in samples from 12 wells ranged from 0.04 to $0.18 \mathrm{mg} / \mathrm{L}$. No wastewater compounds were detected at concentrations above the reporting limits in five wells. Metolachlor was detected in the five samples but at concentrations below the laboratory reporting limit of $0.5 \mu \mathrm{g} / \mathrm{L}$. Caffeine was detected in one sample but also at a concentration below the reporting limit of $0.5 \mu \mathrm{g} / \mathrm{L}$. Samples from the 12 wells were collected by Ohio EPA and analyzed for chloride and nitrate; chloride concentrations ranged from 12.6 to $61.6 \mathrm{mg} / \mathrm{L}$ and nitrate concentrations ranged from 2.34 to $11.9 \mathrm{mg} / \mathrm{L}$. 
Total coliforms were detected concentrations from 2 to $200 \mathrm{CFU} / 100 \mathrm{~mL}$ in eight wells. Similarly, enterococci bacteria were detected in all eight wells sampled, ranging in concentration from 0.5 to 17 $\mathrm{CFU} / 100 \mathrm{~mL}$. E. coli were detected in samples from only three of the eight wells, at concentrations of 1 or $2 \mathrm{CFU} / 100 \mathrm{~mL}$. The test for the human-specific marker, the esp gene, of enterococci was negative in seven samples tested, including the composite sample of HSTS water. The general fecal Bacteriodales marker was detected in samples from four wells, but the tests for both the human- and ruminant-associated markers were negative. The presence of the PCR-detectable DNA for the general fecal Bacteroidales marker is indicative of fecal contamination and recently recharged water.

\section{References Cited}

Baker, D.B., Wallrabenstein, L.,K., Richards, R.P., and Creamer, N.L, 1989, Nitrate and pesticides in private wells of Ohio, a state atlas: Tiffin, Ohio, Heidelberg College, Water Quality Laboratory, part 1, $71 \mathrm{p}$.

Bernhard, A.E., and Field, K.G., 2000, A PCR assay to discriminate human and ruminant feces on the basis of host differences in Bacteroides-Prevotella genes encoding 16S rRNA: Applied and Environmental Microbiology, v. 66, no. 10, p. 4571-4574.

Dick, L.K., Bernhard, A.E., Brodeur, T.J., Walters, S.P., Field, K.G., Santo Domingo, J.W., and Simpson, J.M., 2005, Host distributions of uncultivated fecal Bacteroidales bacteria reveal genetic markers for fecal source identification: Applied and Environmental Microbiology, v. 71, no. 6, p. 3184-3191.

Dumouchelle, D.H, 2006, Assessment of the use of selected chemical and microbiological constituents as indicators of wastewater in curtain drains from home sewage-treatment systems in Medina County, Ohio: U.S. Geological Survey Scientific Investigations Report 2006-5183, 20 p.

Eberts, S.M., Bair, E.S., and de Roche, J.T., 1990, Geohydrology, ground-water quality, and simulated ground-water flow, Geauga County, Ohio: U.S. Geological Survey Water-Resources Investigations Report 90-4026, 117 p.

Francy, D.S., Bushon, R.N., Brady, A.M.G., Kephart, C.M., and Stoeckel, D.M., 2005, Quality assurance/quality control manual for the Ohio Water Microbiology Laboratory, accessed September 19, 2006, at http://oh.water.usgs.gov/micro/lab.html\#qcm

Freeze R.A., and Cherry, J.A., 1979, Groundwater: Englewood Cliffs, N.J., Prentice-Hall, p. 245.

Hem, J.D., 1989, Study and interpretation of the chemical characteristics of natural waters (3d ed.): U.S. Geological Survey Water-Supply Paper 2254, 263 p.

Jagucki, M.L., and Darner, R.A., 2001, Ground-water quality in Geauga County, Ohio-Review of previous studies, status in 1999, and comparison of 1986 and 1999 data: U.S. Geological Survey WaterResources Investigations Report 01-4160, 60 p.

Kreader, C., A., 1998, Persistence of PCR-detectable Bacteroides distasonis from human feces in river water: Applied and Environmental Microbiology, v. 64, no. 10, p. 4103-4105. 
Noble, R.T., Griffith, J.F., Blackwood, A.D., Fuhrman, J.A., Gregory, J.B., Hernandez, X., Liang, X., Bera, A.A., and Schiff, R., 2006, Multitiered approach using quantitative PCR to track sources of fecal pollution affecting Santa Monica Bay, California: Applied and Environmental Microbiology, v. 72, no. 2, p. 1604-1612.

Ohio Environmental Protection Agency, 2006, Unsafe water supply investigation, Wooster Township, Wayne County: Ohio Environmental Protection Agency, Division of Drinking and Ground Waters Fact Sheet, 2 p.

Scott, T.M., Jenkins, T.M., Lukasik, J., and Rose, J.B., 2005, Potential use of a host associated molecular marker in Enterococcus faecium as an index of human fecal pollution: Environmental Science and Technology, v. 39, no. 1, p. 283-287

U.S. Environmental Protection Agency, 2002a, Method 1604-Total coliforms and Escherichia coli in water by membrane filtration using a simultaneous detection technique (MI medium): Washington D.C., EPA 821-R-02-024, 14 p.

U.S. Environmental Protection Agency, 2002b, Method 1600_Enterococci in water by membrane filtration using membrane-enterococcus indoxyl- $\beta$-D-glucoside agar (mEI): Washington, D.C., EPA/821/R-02/022, 9 p.

U.S. Environmental Protection Agency, 2004, List of drinking water contaminants \& MCLs, accessed August 3, 2006, at http://www.epa.gov/safewater/mcl.html

Zaugg, S.D., Smith, S.G., Schroeder, M.P., Barger, L.B., and Burkhardt, M.R., 2002, Methods of analysis by the U.S. Geological Survey National Water Quality Laboratory-Determination of wastewater compounds by polystyrene-divinylbenzene solid-phase extraction and capillary-column gas chromatography/mass spectrometry: U.S. Geological Survey Water-Resources Investigations Report 01-4186, 37 p. 